\title{
Article \\ The Correlation between Play Behavior, Serum Cortisol and Neutrophil-to-Lymphocyte Ratio in Welfare Assessment of Dairy Calves within the First Month of Life
}

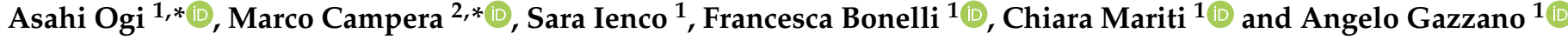 \\ 1 Department of Veterinary Sciences, University of Pisa, 56124 Pisa, Italy; ienco.sara1993@gmail.com (S.I.); \\ francesca.bonelli@unipi.it (F.B.); chiara.mariti@unipi.it (C.M.); angelo.gazzano@unipi.it (A.G.) \\ 2 School of Social Sciences, Oxford Brookes University, Oxford OX3 0BP, UK \\ * Correspondence: a.ogi@hotmail.com (A.O.); mcampera@brookes.ac.uk (M.C.)
}

Citation: Ogi, A.; Campera, M.; Ienco, S.; Bonelli, F.; Mariti, C.; Gazzano, A. The Correlation between Play Behavior, Serum Cortisol and Neutrophil-to-Lymphocyte Ratio in Welfare Assessment of Dairy Calves within the First Month of Life. Dairy 2022, 3, 1-11. https://doi.org/ 10.3390/dairy3010001

Received: 13 November 2021 Accepted: 17 December 2021 Published: 21 December 2021

Publisher's Note: MDPI stays neutral with regard to jurisdictional claims in published maps and institutional affiliations.

Copyright: (C) 2021 by the authors. Licensee MDPI, Basel, Switzerland. This article is an open access article distributed under the terms and conditions of the Creative Commons Attribution (CC BY) license (https:// creativecommons.org/licenses/by/ $4.0 /)$.

\begin{abstract}
Welfare assessment of dairy calves is commonly conducted through the observation of their behavior and the analysis of physiological parameters. Despite the large number of studies on this topic, there is a lack of research on the possible correlation between the physiological parameters and behavior at basal level in dairy calves. For this reason, the present study aimed to investigate the possible correlations between serum cortisol, neutrophil-to-lymphocyte ratio (N/L) and locomotor play behavior in 21 Friesian dairy calves within their first month of life. Every week, an arena test after blood collection was performed. A significant positive correlation between serum cortisol levels and $\mathrm{N} / \mathrm{L}\left(\mathrm{r}_{\mathrm{rm}}=0.381 ; 95 \% \mathrm{CI}=0.083,0.617 ; p=0.012\right)$ and a negative correlation between time spent running and $\mathrm{N} / \mathrm{L}\left(\mathrm{r}_{\mathrm{rm}}=-0.351 ; 95 \% \mathrm{CI}=-0.575,-0.077 ; p=0.012\right)$ were found. On the contrary, no significant correlation between time spent running and cortisol levels was detected. Cortisol levels and $\mathrm{N} / \mathrm{L}$ were higher in the newborn and had a constant decrease until reaching a stable value after the 24th day of life. These findings suggest a better predictivity of N/L, compared to serum cortisol, on locomotor play behavior.
\end{abstract}

Keywords: behavior; calf; cortisol; leukogram; locomotor play; neutrophil-to-lymphocyte ratio; stress; welfare

\section{Introduction}

Animal welfare is playing an increasingly important role in farms' practices [1,2]. The raised concerns about animal wellbeing have considerably changed over the years [3]. Broom himself, in 1991 [4], had to revise and explain his initial approach which seemed to emphasize the importance of the physical state of the animals in assessing their welfare [5]. Duncan, in 1993, defined animal welfare as "all about how an animal feels" [6], emphasizing the role of the emotional state of the animal. During the same year, Rollin pointed out the "naturalness" of domestic animals, and the urge of satisfying their natural needs and desires [7]. The combination of these three key points (basic health and functioning, affective state and natural living) is the basis of the current assessment of welfare $[3,8]$.

If, on the one hand, the analysis of semantic and ethical aspects of animal welfare seems very complex, on the other hand the scientific literature tends to agree that the primary way to gain information on animal wellbeing is through studying their behavior $[9,10]$. Specifically, play behavior is an indicator commonly used for the assessment of positive welfare in young calves [11-13] and other mammals [14-16]. Indeed, play was defined as a "luxury" behavior performed when welfare is not compromised $[17,18]$; the presence of the motivation to play seems to decrease when environmental conditions are poor $[19,20]$. According to Burghardt's five criteria, play behavior is not "fully functional"; it is "autotelic" (self-rewarding); it differs from the "serious" form of the adult; it is performed "repeatedly"; and it is initiated when the animal is in a "relaxed field" (free from threats or intense resource competition) [21]. 
Social play and locomotor play are the two most common types of play recognized in calves $[19,22]$. Locomotor play emerges a few hours after birth, but newborn dairy calves are usually placed in individual pens, where they remain up to 8 weeks of age [23]. The percentage of inactive calves is higher on intensive farms than both pasture and semiintensive farms [24], because the lack of stimuli and, in particular, the deprivation of maternal care and social contacts may compromise the animal welfare and consequently the expression of locomotor activity [25].

The presence of the mother is crucial to improve the welfare of calves because the mother-offspring bond could have a relevant impact in the development of the newborns, not only in altricial [26], but also in precocial species, such as ruminants [27,28]. Moreover, it was found that the presence of the mother is a key factor in eliciting both social and locomotor play behavior $[19,29,30]$.

Another key factor that positively affects the locomotory play behavior is the space allowance [11,22]. For this reason, behavioral assessment of dairy calves is commonly conducted implementing the arena test (also called "open-field" test), which consists of releasing an animal into an open area and observing its behavior for a given period of time [31]. The spatial restriction of the individual pens combined with the space allowance of the arena test is a potential way to increase motivation of calves to perform locomotor play [32]. On the contrary, the presence of companions in the rearing pen was found to influence negatively the motivation to play in the arena [23].

Animals respond to environmental changes with both behavioral modifications and physiological mechanisms. Serum/plasma cortisol concentration is commonly used as biomarker of stress in mammals [33]. However, it is necessary to take into account the influence of circadian rhythm on the hypothalamic-pituitary-adrenal (HPA) axis and the lack of correlation between serum/plasma cortisol concentration and chronic stress [34]. Indeed, an increase in N/L ratio was reported to be more reliable than cortisol levels for long-term environmental changes and chronic stress assessment [35,36]. In fact, it is well established that stressful events cause a glucocorticoids release which is responsible for leukogram changes $[37,38]$. These changes are characterized by neutrophilia and lymphocytopenia, and consequently by an increase in neutrophil-to-lymphocyte ratio $(\mathrm{N} / \mathrm{L})$ [39]. In young calves, the interpretation of the leukogram must be performed carefully, because a high N/L was reported at birth, as well as a sharp fall in the ratio within the first two weeks of life [40]. The stress of labor and the release of corticosteroids at birth seems to be the primary cause of the pattern observed in leukograms of newborns calves [41].

Conforming to the Council Directive 98/58/EC [42] and in agreement with the scientific guidelines [43], the dehorning/disbudding of calves is accepted within the 21st day of age in Italy. However, dehorning can be performed without anesthesia/analgesia by means of cauterization (thermal or chemical) —or, rarely, by means of surgical procedure [44]. In the European Union, dehorning is performed in over $80 \%$ of dairy cattle farms and thermal cauterization is the preferred method for disbudding [1,45]. The procedure is undoubtedly stressful for the calves, and it should be taken into account in assessing potential welfare indicators.

By means of the physiological and behavioral indices, we can interpret the animal's emotional/affective states [8] and welfare [46], but the scientific literature about the possible correlations between these variables in dairy calves is scarce. For this reason, the aim of the present study was to assess the possible correlations between locomotor play, $\mathrm{N} / \mathrm{L}$ and serum cortisol of 21 dairy calves within the first month of life. Moreover, we determined the trend of these parameters over time considering the possible long-term impact of disbudding.

\section{Materials and Methods}

The study took place at the University of Pisa's experimental dairy farm (Centro di Ricerche Agro-Ambientali “E. Avanzi”-CiRAA), where 21 Friesian female dairy calves 
were observed every week from the 3rd to 31st day of age (D3, D10, D17, D24, D31). Calves were kept under the same management conditions. Ready after birth, calves were separated from their dams and fed with $3 \mathrm{~L}$ of good-quality colostrum ( $\geq 50 \mathrm{~g} / \mathrm{L}$ of Ig) evaluated with the optical Atago Brix N1 refractometer (Atago Co., Ltd., Tokyo, Japan) milked from the calves' dam, or from the colostrum bank. Colostrum was administered as soon as the calf could drink (between $30 \mathrm{~min}$ and $2 \mathrm{~h}$ after birth) and between 4 and $8 \mathrm{~h}$ later the first meal. Calves received $3 \mathrm{~L}$ of colostrum, twice a day, until the third day of life [47]. On the fourth day, they received $3 \mathrm{~L}$ of whole milk twice. During the observation period (July 2017-July 2018), the rearing facility housed approximately 60 young subjects under the age of 2 months. Calves were housed in individual straw-bedded pens $(1.4 \mathrm{~m} \times 2.1 \mathrm{~m})$ that allowed them to have visual, olfactory, auditory and some tactile contacts with the other young conspecifics in accordance with European Legislation (2008/119/CE). At the age of 2 months, the calves were weaned and relocated in group pens. The floors of the pens were covered with wheat straw.

Before each behavioral observation (D3, D10, D17, D24, D31), $5 \mathrm{~mL}$ of blood was collected from the jugular vein in the morning between 8 and 9 a.m. A $1 \mathrm{~mL}$ measure was placed in EDTA tubes and analyzed within one hour to perform the blood count $(\mathrm{CBC})$ and to determine the $\mathrm{N} / \mathrm{L}$. The remaining $4 \mathrm{~mL}$ was placed in serum tubes to determine cortisol concentrations. The serum tubes were delivered to the Etovet laboratory of the Department of Veterinary Sciences-University of Pisa (Italy) and then centrifugated $\left(2000 \times g, 4^{\circ} \mathrm{C}\right.$, for $\left.20 \mathrm{~min}\right)$. Serum was stored at $-20^{\circ} \mathrm{C}$ and then the cortisol concentration was determined using the commercial Cortisol ELISA ${ }^{\circledR}$ kit (DIAMETRA Srl, Via Pozzuolo, 14-06038 Spello-Perugia, Italy) previously used in other domestic species [48-50]. The CBC was determined with a ProCyte Dx ${ }^{\circledR}$ Analyser (IDEXX BioAnalytics, Vet Med Labor GmbH, Ludwigsburg, Germany).

Two hours after blood collection, each calf was taken into a large $(4.5 \mathrm{~m} \times 3.3 \mathrm{~m})$ and isolated pen for the quantitative assessment of their behavior. To avoid any stress arising from forced handling, a "luring" method, with a feeding bucket, was used to cover the distance between the iron fence and the experimental pen. The behavior of each calf in the experimental pen was videotaped with a SONY HDR-CX190E for 20 min.

An experienced observer analyzed each video through a continuous sampling method with BORIS ${ }^{\circledR}$, Behavioral Observation Research Interactive Software [51]. The locomotor play behaviors were defined as "State Event" (SE) — when both the number of occurrences and duration of the behaviors were measurable-or "Point Event" (PE), when only the number of occurrences were measurable (Table 1). The relative duration (percentage of total time) of running behavior (SE) and the frequency of the remaining behaviors (PE) were measured and statistically investigated.

A second experienced observer analyzed 12\% (50/420 $\mathrm{min}$ ) of the videos for calculation of inter-rater reliability through the Cohen's kappa coefficient $(\kappa)$. The agreement between the two observers was found to be excellent $(\kappa>0.9)$; therefore, according to Hausman et al. [52], only a single observer video analysis was statistically evaluated.

The disbudding/dehorning of the subjects was carried out between the 17th and the 21st day of age, in compliance with the Italian regulation in force (D. Lgs. 146/2001). A local anesthetic block of the cornual branch of the zygomaticotemporal nerve with $5 \mathrm{~mL} 2 \%$ lidocaine, $20 \mathrm{~min}$ prior to disbudding was used before the electric hot-iron thermocautery. The 21 calves involved in the present study received no nonsteroidal anti-inflammatory drugs (NSAID) treatment. 
Table 1. Ethogram of locomotor play behaviors in Friesian dairy calves. SE: State Event; PE: Point Event.

\begin{tabular}{cl}
\hline Behavior & \multicolumn{1}{c}{ Definition } \\
\hline Running (SE) & Any gait faster than a walk, including trot and gallop. \\
\hline Leap (PE) & $\begin{array}{l}\text { The two forelegs are lifted from the ground and stretched forwards, the forepart of the body } \\
\text { is elevated and the calf moves forward. Movement upwards and forwards. During the last } \\
\text { phase of the movement, the hind legs may be lifted from the ground. }\end{array}$ \\
\hline [22] & $\begin{array}{l}\text { The two forelegs are lifted from the ground, the forepart of the body is elevated. Movement } \\
\text { upwards. During the last phase of the movement, the hind legs may be lifted from the } \\
\text { ground. }\end{array}$ \\
\hline Turn (PE) & $\begin{array}{l}\text { The two forelegs are lifted from the ground and stretched forwards, and as the forepart of } \\
\text { the body is elevated turned to one side, the calf moves sidewards. Movement upwards and } \\
\text { sidewards. During the last phase of the movement, the hind legs may be lifted from the } \\
\text { ground. }\end{array}$ \\
\hline Buck (PE) & $\begin{array}{l}\text { The body ascends from front to back, the top of the head is level with or lower than the } \\
\text { shoulders and both hind hooves are lifted off the ground; legs may be kicked outwards. }\end{array}$ \\
\hline Kick (PE) & $\begin{array}{l}\text { One or both hind legs are lifted off the ground and extended outwards from the body. The } \\
\text { calf can be stationary or moving. }\end{array}$ \\
\hline [35,54]
\end{tabular}

\section{Statistical Analysis}

We ran repeated-measures correlations $\left(\mathrm{r}_{\mathrm{rm}}\right)$ to test the relationships between cortisol, N/L and locomotory play [55]. For locomotory play, we considered either state events (i.e., time spent running), or point events (i.e., sum of the PE of play behaviors: leap, jump, turn, buck and kick). Repeated-measures correlations allow the test of association between two variables while taking into account the non-independence among observations, since we collected data on the same individuals on five different occasions. For cortisol levels and $\mathrm{N} / \mathrm{L}$ ratio, we log transformed the data to meet the assumption of the normality of residuals. For all correlations, we corrected the reference $p$ value for significance with a Benjamini-Hochberg adjustment to avoid a type I error in multiple hypotheses testing and considered the false discovery rate as 0.05 [56].

We tested whether cortisol levels, N/L and locomotory play changed in the first four weeks via Generalized Linear Mixed Models. We used the "glmmTMB" function in the "glmmTMB" package as this function allows different fit families and it is suitable to deal with zero-inflated data. We used individuals as random effect, and age in days as fixed effect. We tested different fit functions (the ones that are included in the package) and included or excluded a zero-inflation term based on the QQ plot residuals and residual vs predicted plot from the package "DHARMa" [45] (available online at https: / cran.r-project. org/web/packages/DHARMa accessed on 12 November 2021). We ran pairwise contrasts using a Bonferroni-Holm post hoc correction via the function "emmeans" in the package "emmeans". We considered $p=0.05$ as level of significance. We ran all the analyses with R v 4.0.4.

\section{Results}

We found a significant but weak positive correlation between cortisol levels and N/L $\left(\mathrm{r}_{\mathrm{rm}}=0.381 ; 95 \% \mathrm{CI}=0.083,0.617 ; p=0.012\right)$ and a negative but weak correlation between time spent running and $\mathrm{N} / \mathrm{L}\left(\mathrm{r}_{\mathrm{rm}}=-0.351 ; 95 \% \mathrm{CI}=-0.575,-0.077 ; p=0.012\right)$ (Figure 1$)$. We detected no significant correlation between time spent running and cortisol levels $\left(r_{\mathrm{rm}}=-0.100 ; 95 \% \mathrm{CI}=-0.332,0.144 ; p=0.415\right)$, between point events of locomotory play and cortisol levels $\left(\mathrm{r}_{\mathrm{rm}}=2212-0.023 ; 95 \% \mathrm{CI}=-0.262,0.218 ; p=0.851\right)$ and between point events of locomotory play and $\mathrm{N} / \mathrm{L}$ ratio $\left(\mathrm{r}_{\mathrm{rm}}=-0.178 ; 95 \% \mathrm{CI}=0.437,0.108 ; p=0.211\right)$.

Cortisol levels and N/L were higher in the newborn and had a constant decrease until reaching a stable value after disbudding (Figure 2). N/L was significantly higher at D3 and D10 compared to D17, D24 and D31 (Table 2). The relative time spent running was 
significantly higher at D24 and D31 than at D3 (Table 2). The point events of locomotory play did not change significantly between times.

(a)

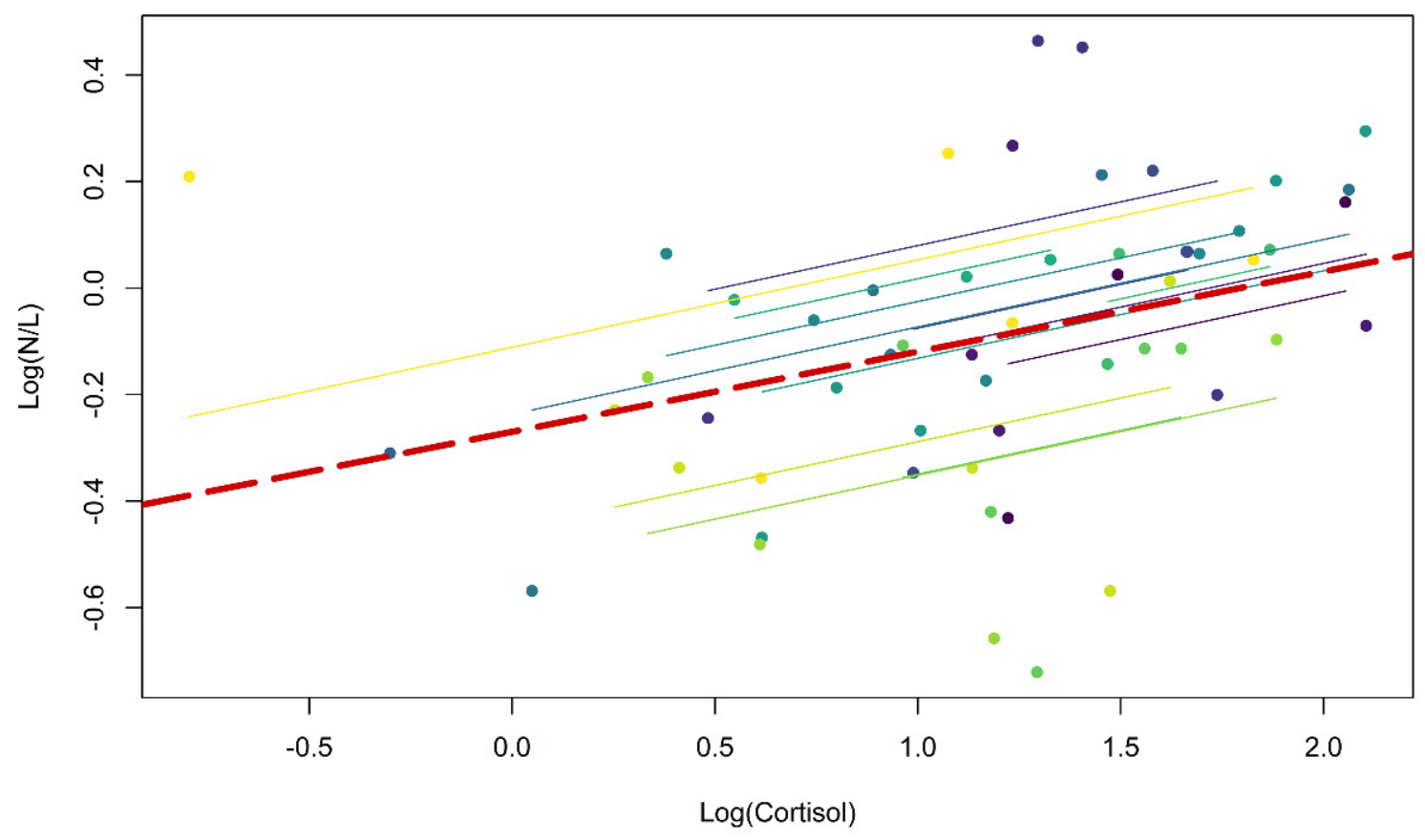

(b)

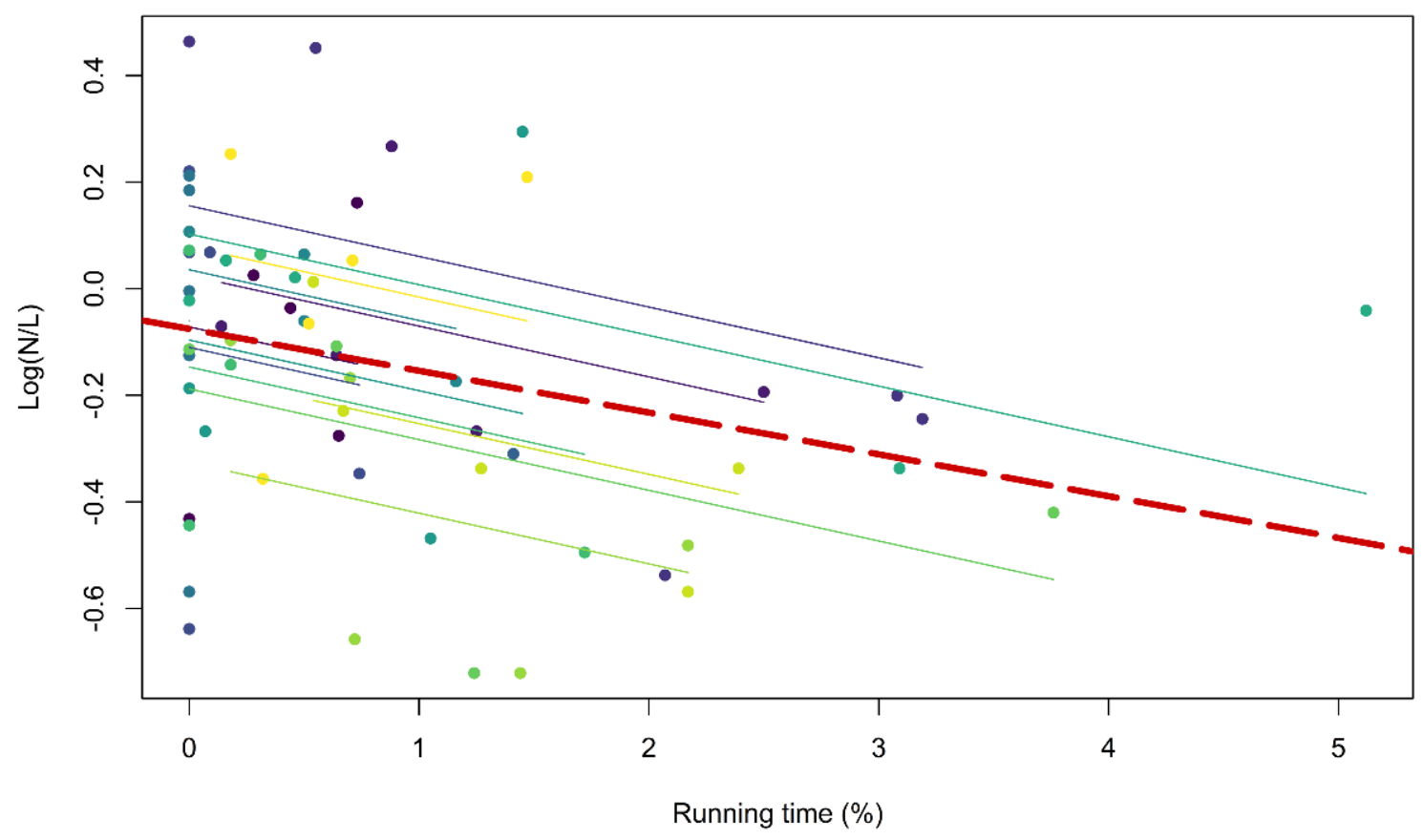

Figure 1. (a) Significant correlation between neutrophil-to-lymphocyte ratio (N/L) and cortisol $\left(r_{r m}=0.381 ; 95 \% C I=0.083,0.617 ; p=0.012\right)$. $(\mathbf{b})$ Significant correlation between $\mathrm{N} / \mathrm{L}$ and relative duration of running $\left(\mathrm{r}_{\mathrm{rm}}=-0.351 ; 95 \% \mathrm{CI}=-0.575,-0.077 ; p=0.015\right)$. Values for $\mathrm{N} / \mathrm{L}$ and cortisol are $\log 10$ transformed. Data are based on 21 dairy calves observed every week from the 3rd to 31st day of age at CiRAA (Centro di Ricerche Agro-Ambientali “E. Avanzi"-University of Pisa). Different colors indicate different individuals, dashed red lines indicate the overall trend. 

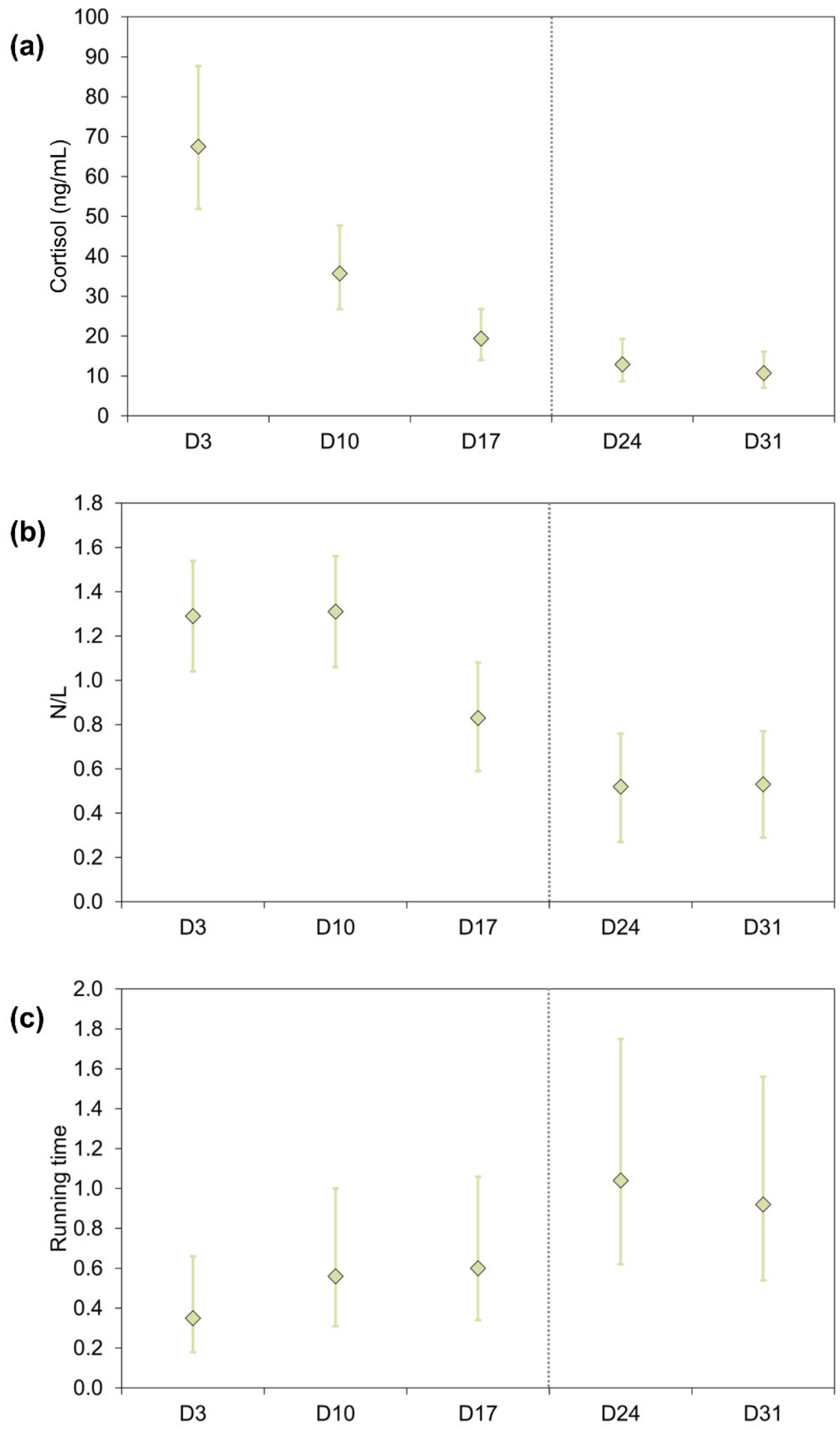

Figure 2. Estimated model means and 95\% confidence intervals based on Generalized Linear Mixed Models to understand the differences in cortisol (a), neutrophil-to-lymphocyte ratio (N/L) (b) and relative time spent running (c). Data are based on 21 dairy calves observed every week from the 3rd to 31st day of age (D3, D10, D17, D24, D31) at CiRAA (Centro di Ricerche Agro-Ambientali “E. Avanzi"-University of Pisa). Dotted lines indicate the approximate time of disbudding. 
Table 2. Significant pairwise comparisons $(p<0.05)$ after pairwise contrasts using a Bonferroni-Holm post hoc correction. Estimated means are in Figure 2. Data are based on 21 dairy calves observed every week from the 3rd to 31st day of age (D3, D10, D17, D24, D31) at CiRAA (Centro di Ricerche Agro-Ambientali “E. Avanzi”-University of Pisa).

\begin{tabular}{|c|c|c|c|c|c|}
\hline Response Variable & Family Fit & Contrast & Ratio & $95 \%$ CI & t-Value \\
\hline \multirow[t]{8}{*}{ Cortisol } & \multirow[t]{8}{*}{ Tweedie } & D3/D10 & 1.89 & $1.07-3.33$ & 3.24 \\
\hline & & D3/D17 & 3.49 & $1.90-6.39$ & 5.94 \\
\hline & & $\mathrm{D} 3 / \mathrm{D} 24$ & 5.22 & $2.61-10.45$ & 6.88 \\
\hline & & D3/D31 & 6.33 & $3.12-12.85$ & 7.52 \\
\hline & & D10/D17 & 1.84 & $0.98-3.47$ & 2.80 \\
\hline & & D10/D24 & 2.76 & $1.35-5.65$ & 4.10 \\
\hline & & D10/D31 & 3.35 & $1.62-6.95$ & 4.78 \\
\hline & & D17/D31 & 1.82 & $0.85-3.89$ & 2.26 \\
\hline \multirow[t]{6}{*}{$\mathrm{N} / \mathrm{L}$} & \multirow[t]{6}{*}{ Gaussian } & D3/D17 & 1.93 & $0.93-2.93$ & 2.85 \\
\hline & & D3/D24 & 3.04 & $1.24-4.83$ & 4.83 \\
\hline & & D3/D31 & 3.04 & $1.23-4.84$ & 4.84 \\
\hline & & D10/D17 & 1.95 & $0.94-2.96$ & 2.96 \\
\hline & & D10/D24 & 3.10 & $1.26-4.93$ & 4.93 \\
\hline & & D10/D31 & 3.10 & $1.24-4.95$ & 4.95 \\
\hline \multirow{2}{*}{ Running time } & \multirow{2}{*}{$\begin{array}{l}\text { Tweedie-zero } \\
\text { inflated }\end{array}$} & D3/D24 & 0.33 & $0.12-0.90$ & -3.16 \\
\hline & & D3/D31 & 0.38 & $0.35-1.04$ & -2.72 \\
\hline
\end{tabular}

\section{Discussion}

Dairy calves' play behavior is easy to recognize, it can be measured noninvasively and it is a cause and, at the same time, a consequence of good welfare [16,32]. Therefore, to improve the wellbeing of these mammals, play behavior should be allowed to be expressed to a greater extent, by ensuring a more gradual cow-calf separation and/or larger pens to keep calves together, ensuring them an adequate environmental and social stimulation [24]. For the present study, we excluded some behaviors reported as possible play behaviors [11,22]: head shaking, rubbing or scratching, ear flicking, tail swishing, quick transition from standing to lying and vocalization, because those behaviors could be also markers of stress or pain [32,43,57-59].

We found no significant correlations between the point events (PE) of locomotory play and cortisol levels or N/L. Therefore, we focused the discussion on the relative duration of running in the arena (percentage of total time spent by the calves running in the arena during the $20 \mathrm{~min}$ of observation). The relative time spent running by the calves tended to increase during the first 24 days of observation (D24 > D17 > D10 > D3). Indeed, the highest duration of running was observed at D24 and the time spent running at D31 was slightly lower than at D24.

The disbudding protocol adopted at CiRAA includes an evaluation of pain and, in case the calf shows clear signs of pain, NSAID are administered. According to Faulkner and Weary, in fact, the recommended treatment to prevent disbudding-related stress and pain is a combination of three drugs: a sedative, a local anesthetic and an NSAID [58]. Despite the disbudding procedure adopted for the 21 calves involved in the present study was carried out with only local anesthesia, no significant difference was observed between D17 and D24 for all the examined parameters. Moreover, the highest peak of running behavior and the lowest level of N/L were observed at D24. Therefore, it could be assumed that the pain did not negatively influence the long-term wellbeing of the calves and, accordingly, the pattern of physiological parameters reported in this study should be considered at basal level. Moreover, the peak of plasma cortisol seems to occur between 20 and 30 min after the hot-iron disbudding $[57,60]$ and 60 min after the paste disbudding because the caustic burns continue to cause tissue damage while the thermal burns are only temporary [61]. The corticosteroid release is normally preceded by marked pain-related behaviors when the anesthetic treatment is not performed [61]. In general, the duration of the effects of 
hot-iron disbudding seem to not exceed $24-27 \mathrm{~h}[32,58]$, although some authors previously reported effects not exceeding $4 \mathrm{~h}$ [62].

The trend of N/L over time is consistent with previous studies in dairy calves $[63,64]$ and beef calves [40]. Furthermore, the serum cortisol concentration decreased from D3 to D31 as previously reported [63-65]. The significant positive correlations between N/L and serum cortisol may constitute further evidence that glucocorticoids and leukogram are linked both at basal level and after a stress release. Since the physiological responses to the environment has been considered a more objective measurement of stress than behavioral observation [66], investigating both N/L and serum cortisol has integrated and amplified the significance of locomotor play behavior. In this regard, a significant negative correlation between N/L and running was found, while the lack of the same correlation between serum cortisol and running would seem to recognize a limited association between the HPA axis and play behavior at basal level. Moreover, the present findings could be representative of a higher predictivity of $\mathrm{N} / \mathrm{L}$, compared to serum cortisol, on locomotor play behavior.

Despite the fact that N/L is largely considered a measure of the stress response [67], conventionally, stress is estimated by measuring circulating cortisol concentration $[66,68]$. Blood sampling is an invasive medical procedure and cortisol could offer the advantage of being measured non-invasively in saliva $[48,69]$ and hair [70-72]. However, when a withdrawal is required, N/L might still be a good biomarker because determining a stress leukogram is a quicker and cheaper procedure compared to determining plasma/serum cortisol [73].

\section{Conclusions}

Despite the scientific literature on N/L, serum cortisol and locomotor play behavior in assessing the welfare of dairy calves is quite consistent, the correlation between these parameters is not widely described. The present study found a better predictivity of N/L, compared to serum cortisol, on locomotor play behavior, and a significant correlation between N/L and serum cortisol at basal level. Considering the advantages of assessing stress levels with N/L instead of cortisol, our findings could contribute to improving the possible application of this parameter. Further research into the variation and correlation between these parameters towards different stimuli is needed to elucidate the possible involvement of $\mathrm{N} / \mathrm{L}$ in stress assessment of dairy calves.

Author Contributions: Conceptualization, A.O. and A.G.; methodology, A.O., A.G.; formal analysis, M.C.; investigation, A.O., A.G. and S.I.; resources, A.G. and F.B.; data curation, A.O., M.C. and S.I.; writing-original draft preparation, A.O.; writing—review and editing, A.O., M.C., F.B., C.M. and A.G.; supervision, A.G. All authors have read and agreed to the published version of the manuscript.

Funding: This research received no external funding.

Institutional Review Board Statement: The study was approved by the Ethics Committee of the University of Pisa, Italy (Decision \#2/2017) in accordance with Directive 2010/63/EU.

Informed Consent Statement: Not applicable.

Data Availability Statement: The data presented in this study are available on request from the corresponding authors.

Acknowledgments: The authors would like to thank the staff of the University of Pisa's experimental dairy farm (Centro di Ricerche Agro-Ambientali “E. Avanzi”-CiRAA).

Conflicts of Interest: The authors declare no conflict of interest.

\section{References}

1. Cozzi, G.; Gottardo, F.; Brscic, M.; Contiero, B.; Irrgang, N.; Knierim, U.; Pentelescu, O.; Windig, J.J.; Mirabito, L.; Kling Eveillard, F.; et al. Dehorning of cattle in the EU Member States: A quantitative survey of the current practices. Livest. Sci. 2015, 179, 4-11. [CrossRef]

2. Tremetsberger, L.; Winckler, C. Effectiveness of animal health and welfare planning in dairy herds: A review. Anim. Welf. 2015, 24, 55-67. [CrossRef] 
3. Fraser, D.; Fraser, D. The role of the veterinarian in animal welfare. Animal welfare: Too much or too little? Abstracts of the 21st Symposium of the Nordic Committee for Veterinary Scientific Cooperation (NKVet), Vaerløse, Denmark, 24-25 September 2007. Acta Vet. Scand. 2008, 50. [CrossRef]

4. Broom, D.M. Animal welfare: Concepts and measurement. J. Anim. Sci. 1991, 69, 4167-4175. [CrossRef] [PubMed]

5. Broom, D.M. Indicators of poor welfare. Br. Vet. J. 1986, 142, 524-526. [CrossRef]

6. Duncan, I.J.H. Welfare Is to Do with What Animals Feel. J. Agric. Environ. Ethics 1993, 6, 8-14.

7. Rollin, B.E. Animal welfare, science, and value. J. Agric. Environ. Ethics 1993, 6, 44-50.

8. Hemsworth, P.H.; Mellor, D.J.; Cronin, G.M.; Tilbrook, A.J. Scientific assessment of animal welfare. N. Z. Vet. J. 2015, 63, 24-30. [CrossRef] [PubMed]

9. Bekoff, M. Animal emotions: Exploring passionate natures. Bioscience 2006, 50, 861. [CrossRef]

10. Gonyou, H.W. Why the study of animal behavior is associated with the animal welfare issue. J. Anim. Sci. 1994, 72, 2171-2177. [CrossRef]

11. Jensen, M.B.; Kyhn, R. Play behaviour in group-housed dairy calves, the effect of space allowance. Appl. Anim. Behav. Sci. 2000, 67, 35-46. [CrossRef]

12. Rushen, J.; Wright, R.; Johnsen, J.F.; Mejdell, C.M.; de Passillé, A.M. Reduced locomotor play behaviour of dairy calves following separation from the mother reflects their response to reduced energy intake. Appl. Anim. Behav. Sci. 2016, 177, 6-11. [CrossRef]

13. Keeling, L.J.; Winckler, C.; Hintze, S.; Forkman, B. Towards a positive welfare protocol for cattle: A critical review of indicators and suggestion of how we might proceed. Front. Anim. Sci. 2021, 2, 1-19. [CrossRef]

14. Fraser, D.; Duncan, I.J.H. "Pleasures", "pains" and animal welfare: Toward a natural history of affect. Anim. Welf. 1998, 7 , 383-396.

15. Spinka, M.; Newberry, R.C.; Bekoff, M. Mammalian play: Training for the unexpected. Q. Rev. Biol. 2004, 76, 141-168. [CrossRef]

16. Held, S.D.E.; Špinka, M. Animal play and animal welfare. Anim. Behav. 2011, 81, 891-899. [CrossRef]

17. Dawkins, M.S. Battery hens name their price. Anim. Behav. 1983, 31, 1195-1205. [CrossRef]

18. Lawrence, A. Consumer demand theory and the assessment of animal welfare. Anim. Behav. 1987, 35, 293-295. [CrossRef]

19. Boissy, A.; Manteuffel, G.; Jensen, M.B.; Moe, R.O.; Spruijt, B.; Keeling, L.J.; Winckler, C.; Forkman, B.; Dimitrov, I.; Langbein, J.; et al. Assessment of positive emotions in animals to improve their welfare. Physiol. Behav. 2007, 92, 375-397. [CrossRef]

20. Ahloy-Dallaire, J.; Espinosa, J.; Mason, G. Play and optimal welfare: Does play indicate the presence of positive affective states? Behav. Process. 2018, 156, 3-15. [CrossRef]

21. Burghardt, G.M. The Genesis of Animal Play: Testing the Limits; MIT Press: Cambridge, MA, USA, 2005 ; ISBN 0262025434.

22. Jensen, M.B.; Vestergaard, K.S.; Krohn, C.C. Play behaviour in dairy calves kept in pens: The effect of social contact and space allowance. Appl. Anim. Behav. Sci. 1998, 56, 97-108. [CrossRef]

23. Valníčková, B.; Stěhulová, I.; Šárová, R.; Špinka, M. The effect of age at separation from the dam and presence of social companions on play behavior and weight gain in dairy calves. J. Dairy Sci. 2015, 98, 5545-5556. [CrossRef]

24. Hintze, S.; Maulbetsch, F.; Asher, L.; Winckler, C. Doing nothing and what it looks like: Inactivity in fattening cattle. PeerJ 2020, 8 , e9395. [CrossRef]

25. Lidfors, L.M. Behavioural effects of separating the dairy calf immediately or 4 days post-partum. Appl. Anim. Behav. Sci. 1996, 49, 269-283. [CrossRef]

26. Guardini, G.; Bowen, J.; Mariti, C.; Fatjó, J.; Sighieri, C.; Gazzano, A. Influence of maternal care on behavioural development of domestic dogs (Canis familiaris) living in a home environment. Animals 2017, 7, 93. [CrossRef] [PubMed]

27. Orihuela, A.; Mota-Rojas, D.; Strappini, A.; Serrapica, F.; Braghieri, A.; Mora-Medina, P.; Napolitano, F. Neurophysiological mechanisms of cow-calf bonding in buffalo and other farm animals. Animals 2021, 11, 1968. [CrossRef]

28. Orihuela, A.; Galina, C.S. Effects of separation of cows and calves on reproductive performance and animal welfare in tropical beef cattle. Animals 2019, 9, 223. [CrossRef] [PubMed]

29. Weary, D.M.; Chua, B. Effects of early separation on the dairy cow and calf. Appl. Anim. Behav. Sci. 2000, 69, 177-188. [CrossRef]

30. Flower, F.C.; Weary, D.M. Effects of early separation on the dairy cow and calf: 2. Separation at 1 day and 2 weeks after birth. Appl. Anim. Behav. Sci. 2001, 70, 275-284. [CrossRef]

31. Mintline, E.M.; Wood, S.L.; de Passillé, A.M.; Rushen, J.; Tucker, C.B. Assessing calf play behavior in an arena test. Appl. Anim. Behav. Sci. 2012, 141, 101-107. [CrossRef]

32. Mintline, E.M.; Stewart, M.; Rogers, A.R.; Cox, N.R.; Verkerk, G.A.; Stookey, J.M.; Webster, J.R.; Tucker, C.B. Play behavior as an indicator of animal welfare: Disbudding in dairy calves. Appl. Anim. Behav. Sci. 2013, 144, 22-30. [CrossRef]

33. Spencer, R.L.; Deak, T. A users guide to HPA axis research. Physiol. Behav. 2017, 178, 43-65. [CrossRef] [PubMed]

34. Lee, D.Y.; Kim, E.; Choi, M.H. Technical and clinical aspects of cortisol as a biochemical marker of chronic stress. BMB Rep. 2015, 48, 209-216. [CrossRef] [PubMed]

35. Gross, W.B.; Siegel, H.S. Evaluation of the Heterophil/Lymphocyte Ratio as a Measure of Stress in Chickens. Avian Dis. 1983, 27, 972. [CrossRef]

36. Swan, M.P.; Hickman, D.L. Evaluation of the neutrophil-lymphocyte ratio as a measure of distress in rats. Lab Anim. 2014, 43, 276-282. [CrossRef]

37. Kent, J.E.; Ewbank, R. The effect of road transportation on the blood constituents and behaviour of calves. II. One to three weeks old. Br. Vet. J. 1986, 142, 131-140. [CrossRef] 
38. Weber, P.S.D.; Toelboell, T.; Chang, L.-C.; Tirrell, J.D.; Saama, P.M.; Smith, G.W.; Burton, J.L. Mechanisms of glucocorticoid-induced down-regulation of neutrophil L-selectin in cattle: Evidence for effects at the gene-expression level and primarily on blood neutrophils. J. Leukoc. Biol. 2004, 75, 815-827. [CrossRef]

39. Lomborg, S.R.; Nielsen, L.R.; Heegaard, P.M.H.; Jacobsen, S. Acute phase proteins in cattle after exposure to complex stress. Vet. Res. Commun. 2008, 32, 575-582. [CrossRef]

40. Da Costa, M.C.; da Flaiban, K.K.M.C.; Coneglian, M.M.; Dognani, R.; Vettorato, E.D.; Balarin, M.R.S.; Lisbôa, J.A.N. Metabolismo oxidativo dos neutrófilos de bezerros das raças Nelore e Limousin nos primeiros quatro meses de vida. Pesqui. Vet. Bras. 2008, 28, 431-436. [CrossRef]

41. Benesi, F.J.; Teixeira, C.M.C.; Leal, M.L.R.; Lisboa, J.A.N.; Mirandola, R.M.S.; Shecaira, C.L.; Gomes, V. Leukograms of healthy Holstein calves within the first month of life. Pesqui. Vet. Bras. 2012, 32, 352-356. [CrossRef]

42. Council of European Union. Council Directive 98/58/EC of 20 July 1998 concerning the protection of animals kept for farming purposes. Off. J. Eur. Commun. 1998, 221, 23-27.

43. Stilwell, G.; Carvalho, R.C.; Carolino, N.; Lima, M.S.; Broom, D.M. Effect of hot-iron disbudding on behaviour and plasma cortisol of calves sedated with xylazine. Res. Vet. Sci. 2010, 88, 188-193. [CrossRef]

44. Kupczyński, R.; Budny, A.; Śpitalniak, K.; Tracz, E. Dehorning of calves-Methods of pain and stress alleviation-A review. Ann. Anim. Sci. 2014, 14, 231-243. [CrossRef]

45. Gottardo, F.; Nalon, E.; Contiero, B.; Normando, S.; Dalvit, P.; Cozzi, G. The dehorning of dairy calves: Practices and opinions of 639 farmers. J. Dairy Sci. 2011, 94, 5724-5734. [CrossRef]

46. Munksgaard, L.; Simonsen, H.B. Behavioral and pituitary adrenal-axis responses of dairy cows to social isolation and deprivation of lying down. J. Anim. Sci. 1996, 74, 769. [CrossRef]

47. Turini, L.; Conte, G.; Bonelli, F.; Sgorbini, M.; Madrigali, A.; Mele, M. The relationship between colostrum quality, passive transfer of immunity and birth and weaning weight in neonatal calves. Livest. Sci. 2020, 238, 104033. [CrossRef]

48. Ogi, A.; Mariti, C.; Baragli, P.; Sergi, V.; Gazzano, A. Effects of stroking on salivary oxytocin and cortisol in guide dogs: Preliminary results. Animals 2020, 10, 708. [CrossRef] [PubMed]

49. Tatara, M.R.; Krupski, W.; Tymczyna, B.; Łuszczewska-sierakowska, I. Biochemical bone metabolism markers and morphometric, densitometric and biomechanical properties of femur and tibia in female and gonadectomised male Polish Landrace pigs. $J$. Pre-Clin. Clin. Res. 2012, 6, 14-19.

50. Ekiz, B.; Ergul Ekiz, E.; Kocak, O.; Yalcintan, H.; Yilmaz, A. Effect of pre-slaughter management regarding transportation and time in lairage on certain stress parameters, carcass and meat quality characteristics in Kivircik lambs. Meat Sci. 2012, 90, 967-976. [CrossRef] [PubMed]

51. Friard, O.; Gamba, M. BORIS: A free, versatile open-source event-logging software for video/audio coding and live observations. Methods Ecol. Evol. 2016, 7, 1325-1330. [CrossRef]

52. Hausman, N.L.; Javed, N.; Bednar, M.K.; Guell, M.; Schaller, E.; Nevill, R.E.; Kahng, S. Interobserver agreement: A preliminary investigation into how much is enough? J. Appl. Behav. Anal. 2021, 9999, 1-12. [CrossRef]

53. Sutherland, M.A.; Worth, G.M.; Schütz, K.E.; Stewart, M. Rearing substrate and space allowance influences locomotor play behaviour of dairy calves in an arena test. Appl. Anim. Behav. Sci. 2014, 154, 8-14. [CrossRef]

54. Sutherland, M.A.; Worth, G.M.; Cameron, C.; Ross, C.M.; Rapp, D. Health, physiology, and behavior of dairy calves reared on 4 different substrates. J. Dairy Sci. 2017, 100, 2148-2156. [CrossRef] [PubMed]

55. Bakdash, J.Z.; Marusich, L.R. Repeated Measures Correlation. Front. Psychol. 2017, 8, 456. [CrossRef]

56. Benjamini, Y.; Hochberg, Y. Controlling the false discovery rate: A practical and powerful approach to multiple testing. J. R. Stat. Soc. Ser. B 1995, 57, 289-300. [CrossRef]

57. Graf, B.; Senn, M. Behavioural and physiological responses of calves to dehorning by heat cauterization with or without local anaesthesia. Appl. Anim. Behav. Sci. 1999, 62, 153-171. [CrossRef]

58. Faulkner, P.M.; Weary, D.M. Reducing pain after dehorning in dairy calves. J. Dairy Sci. 2000, 83, 2037-2041. [CrossRef]

59. Caray, D.; de Boyer des Roches, A.; Frouja, S.; Andanson, S.; Veissier, I. Hot-iron disbudding: Stress responses and behavior of 1- and 4-week-old calves receiving anti-inflammatory analgesia without or with sedation using xylazine. Livest. Sci. 2015, 179, 22-28. [CrossRef]

60. Stafford, K.J.; Mellor, D.J. Dehorning and disbudding distress and its alleviation in calves. Vet. J. 2005, 169, 337-349. [CrossRef]

61. Stilwell, G.; de Carvalho, R.C.; Lima, M.S.; Broom, D.M. Effect of caustic paste disbudding, using local anaesthesia with and without analgesia, on behaviour and cortisol of calves. Appl. Anim. Behav. Sci. 2009, 116, 35-44. [CrossRef]

62. Morisse, J.P.; Cotte, J.P.; Huonnic, D. Effect of dehorning on behaviour and plasma cortisol responses in young calves. Appl. Anim. Behav. Sci. 1995, 43, 239-247. [CrossRef]

63. Panivivat, R.; Kegley, E.B.; Pennington, J.A.; Kellogg, D.W.; Krumpelman, S.L. Growth performance and health of dairy calves bedded with different types of materials. J. Dairy Sci. 2004, 87, 3736-3745. [CrossRef]

64. Higginbotham, G.E.; Stull, C.L. Performance and health of dairy calves using different types of commercial housing. Prof. Anim. Sci. 1997, 13, 18-23. [CrossRef]

65. Coleman, D.A.; Moss, B.R.; McCaskey, T.A. Supplemental shade for dairy calves reared in commercial calf hutches in a southern climate. J. Dairy Sci. 1996, 79, 2038-2043. [CrossRef]

66. Hart, K.A. The use of cortisol for the objective assessment of stress in animals: Pros and cons. Vet. J. 2012, 192, 137-139. [CrossRef] 
67. Almoosavi, S.M.M.S.; Ghoorchi, T.; Naserian, A.A.; Ramezanpor, S.S.; Ghaffari, M.H. Long-term impacts of late-gestation maternal heat stress on growth performance, blood hormones and metabolites of newborn calves independent of maternal reduced feed intake. Domest. Anim. Endocrinol. 2020, 72, 106433. [CrossRef] [PubMed]

68. Veissier, I.; de la Fe, A.R.; Pradel, P. Nonnutritive oral activities and stress responses of veal calves in relation to feeding and housing conditions. Appl. Anim. Behav. Sci. 1998, 57, 35-49. [CrossRef]

69. Bonelli, F.; Rota, A.; Aurich, C.; Ille, N.; Camillo, F.; Panzani, D.; Sgorbini, M. Determination of salivary cortisol in donkey stallions. J. Equine Vet. Sci. 2019, 77, 68-71. [CrossRef]

70. Burnett, T.A.; Madureira, A.M.L.; Silper, B.F.; Tahmasbi, A.; Nadalin, A.; Veira, D.M.; Cerri, R.L.A. Relationship of concentrations of cortisol in hair with health, biomarkers in blood, and reproductive status in dairy cows. J. Dairy Sci. 2015, 98, 4414-4426. [CrossRef]

71. Comin, A.; Prandi, A.; Peric, T.; Corazzin, M.; Dovier, S.; Bovolenta, S. Hair cortisol levels in dairy cows from winter housing to summer highland grazing. Livest. Sci. 2011, 138, 69-73. [CrossRef]

72. Comin, A.; Peric, T.; Corazzin, M.; Veronesi, M.C.; Meloni, T.; Zufferli, V.; Cornacchia, G.; Prandi, A. Hair cortisol as a marker of hypothalamic-pituitary-adrenal axis activation in Friesian dairy cows clinically or physiologically compromised. Livest. Sci. 2013, 152, 36-41. [CrossRef]

73. Davis, A.K.; Maney, D.L.; Maerz, J.C. The use of leukocyte profiles to measure stress in vertebrates: A review for ecologists. Funct. Ecol. 2008, 22, 760-772. [CrossRef] 